\title{
Consolidation of Administrative Services in Indonesia Study on Formation of Sub-District (Urban Area) in Karawang Regency West Java Province
}

\author{
Fernandes Simangunsong1, Imelda Hutasoit ${ }^{2}$ \\ ${ }^{1}$ Institut Pemerintahan Dalam Negeri (Governmental Institute of Home Affairs), Sumedang-Jawa Barat, Indonesia \\ ${ }^{2} J$ l. Raya Bandung-Sumedang Km. 20 Jatinangor, Sumedang-Jawa Barat, Indonesia \\ Email: kisankiel@yahoo.co.id, fernandes_simangunsong@ipdn.ac.id, www.fernandessimangunsong.com, \\ imelda77_soit@yahoo.com
}

How to cite this paper: Simangunsong, F. and Hutasoit, I. (2018) Consolidation of Administrative Services in Indonesia Study on Formation of Sub-District (Urban Area) in Karawang Regency West Java Province. Open Journal of Social Sciences, 6, 131-155. https://doi.org/10.4236/jss.2018.67011

Received: May 22, 2018

Accepted: July 24, 2018

Published: July 27, 2018

Copyright $\odot 2018$ by authors and Scientific Research Publishing Inc. This work is licensed under the Creative Commons Attribution International License (CC BY 4.0).

http://creativecommons.org/licenses/by/4.0/

\begin{abstract}
This paper is aimed to provide description on capability level in 2 (two) sub-districts to be formed in West Karawang district, i.e. Karangpawitan and Tanjungpura, and provide description on public aspiration on the plan of formation of sub-districts of Karangpawitan and Tanjungpura, to provide description on the availability and quality of public services provided by Karangpawitan sub-district and Tanjungpura sub-district all this time. This study uses application of regional capacity assessment model, by applying saturated sampling, namely listing all Community Associations (Rukun Warga) (RW) in Karangpawitan sub-district and Tanjungpura sub-district. Conclusion from this study will provide recommendation for Karawang Regency Government to implement formation of both sub-districts with several alternatives of regional reorganization of Community Associations (RWs) systematically, gradually, and continuously.
\end{abstract}

\section{Keywords}

Regional Development, Local Government, Sub-District (Urban Area), Community Association (RW), Public Policy

\section{Introduction}

In Government Regulation No. 19 of 2008 on District, it is clearly stated that formation of new district can be dividing of one district into two or more new districts; and/or integration of villages and/or sub-districts from several districts. 
In Article 3 of this Government Regulation, it is also stated that formation of district requires several requirements, namely: administrative, technical, and territorial physical [1].

Philosophically, district that is headed by Camat (district head) needs to be consolidated on the aspects of facilities of infrastructures, administrative system, financial and authority of administration, in the governmental administration of district as a characteristic of territorial administration with strategic position in relation with administration of regency/city government headed by regent/mayor [2].

Regarding to sub-district, it also went through changes since the enactment of Law No. 23 of 2014 on Local Government in lieu of Law No. 32 of 2014. Here, position of sub-district according to Law No. 32 of 2004 is an local government agency (Satuan Kerja Pemerintah Daerah (SKPD)) (LGA), but then is changed according to Law No. 23 of 2014, that now it is a district agency. One thing for sure is that sub-district is an administrative region under district. In the context of regional autonomy, sub-district is operational area of lurah (sub-district head) as the local agency of regency/city. Sub-district is headed by lurah with status of Civil Servant. Sub-district is the lowest government unit at the same level of administrative village. To be distinguished from village, sub-district has right to manage the more limited area. In its development, village that is entitled with more extensive authority can have its status changed into sub-district. Position of sub-district in Law No. 23 of 2014 is different with previous law, despite the fact that position of district is still the same. At the time Law No. 22 of 1999 and Law No. 32 of 2004 were in effect, Camat was no longer a regional leader, but a local agency/LGA. In Article 123 clause (2) Law No. 32 of 2004, it is stated that local agency of regency/city includes regional secretary, secretary of $D P R D$, local office, regional technical institution, district, and sub-district. So legally, position of Camat is in line with local office head and lurah. This positioning makes Camat and lurah have full authority and be autonomous in the administration of political decision making in their region [3] (Simangunsong, 2014).

Furthermore, Article 208 clause (1) Law No. 23 of 2014 regulates that regional leader and $D P R D$ in the implementation of administrative affairs are assisted by Local Agency. According to Article 209 clause (2), it is stated that Local Agency of Regency/City includes: a) Regional Secretary, b) Secretary of DPRD, c) Inspectorate, d) Office, e) Agency, and f) District. Sub-district is excluded. It means that sub-district is not part of local agency anymore. This is different compared with two previous regulations that explicitly stated that sub-district is a local agency. As a result, delegation of authority both administratively and politically from regent/city to sub-district also changes.

Differences of Sub-district as LGA (Local Agency) and Non-LGA are as shown in Table 1:

Growing aspiration that demands for regional development and reorganization in Karawang Regency, specifically Formation of Sub-district in Karawang Regency, needs to be responded by concerned parties, especially by $D P R D$ as 
Table 1. Sub-district in law no. 32 of 2004 and law no. 23 of 2014.

No Aspect Sub-district as Local Agency Law No. 32 of $2004 \quad$ Sub-district as Non-Local Agency Law No. 23 of

1 Judicial In Article 120 clause (2) Law No. 32 of 2004, sub-district is local Regulation agency together with regional secretary, secretary of $D P R D$, local office, regional technical institution, and district.

2 Definition of Regulation of Minister of Home Affairs No. 36 of 2007, sub-district operational area of lurah as local agency of regency/city is in operational area of district.

3 Authority a) Implementing agency for political decentralization (devolution
-Delegation of authority).

b) Implementing administrative affairs delegated by regent/mayor (Article 2 Regulation of Minister of Home Affairs No. 36 of 2007 on Delegation of Administrative Affairs of Regency/City to lurah).
Article 209 clause (2) Law No. 23 of 2014, sub-district is not a local agency.

It does not specify the definition beside condition for its creation by Regional regulation (Article 229 clause (1)).

Only to the level of district are authorized to implement administrative affairs under the authority of Local government and assisting duty (Article 209 (3)).

\section{Article 229 Law No. 23 of 2014}

It is stated that it is to assist camat in:

a) implementation of administrative activities of sub-district;

b) implementatin of public empowerment;

c) implementation of public service;

d) maintenance of public security and order; and e) maintenance of public facilities and infrastructures; f) implementation of other duties as delegated by camat;

g) implementation of other duties as stipulated;

h) in laws and regulations.
$5 \quad$ Planning

6 Budgeting

7 Authority a) implementation of adr

c) public service;

d) implementation of public security and order; and

Regulation of Minister of Home Affairs No. 36 of 2007

a) Sub-district is operational area of luras as the local agency of regency/city within operational area of District (Article 1).

b) Lurah is authorized to implement administrative, development, and social affairs (Article 2 clause (1)).

c) Lurah implements administrative affairs as delegated by regent/mayor. (Article 2 clause (2)).

d) Regent/mayor delegates administrative affairs to lurah in accordance with the needs of sub-district, by considering efficiency and accountability (Article 3).

e) Administrative affairs of regency/city delegated by regent/mayor to lurah are mandatory affairs and optional affairs (Article 5 clause (1)).

f) Further provision shall be stipulated in Regulation of Regent/Mayor (Article 5 clause (2)).

Entitled with autonomy to make its own Strategic Plan according to public needs.

Entitled with autonomy to prepare its own budgeting according to the needs and Strategic Plan.

Given by regent/mayor according to the needs of lurah, of both mandatory and optional affairs.
Not entitled with autonomy to make its own Strategic Plan Strategic Plan is made as part of District's Strategic Plan.

Depending on availability of fund and District's Strategic Plan.

Limited in the implementation of duties given by camat.

Source: Processed and analyzed by Authors from Law No. 32 of 2004 and Law No. 23 of 2014.

people's representatives and also local government. This is in line with explanation of Law No. 32 of 2004, as replaced by Law No. 23 of 2014, that implementation of regional autonomy should always be oriented towards improvement of social welfare by considering public interests and public aspiration, specifically to open access to isolated region of Karawang Regency as a normative commu- 
nity, economic entity, cultural environment, environmental unit, and as a political sub-system of West Java Province. The question is whether this aspiration can assure the improvement of public services and social welfare in Karawang Regency. For that purpose, it is necessary to conduct a study on potential and problems in sub-districts in Karawang Regency, and also to explore public aspiration.

Facts above suggest that in the implementation of regional autonomy, there are many formation/creation of regions, of either province, regency/city, district, sub-district and village. This is understandable, since the essence of formation/creation of region is to bring government agencies' service nearer to community. By formation/creation of region, it is expected that purposes of regional autonomy policy, such as improved public services, democratization and public empowerment can be achieved, despite the fact that, in Law No. 32 of 2004 as replaced by Law No. 23 of 2014, requirements for creation/formation of sub-district have been revised, specifically the technical and physical requirements.

Following the issuance of Law No. 23 of 2014, Central Government is preparing government regulation on district and sub-district to replace GR No. 19 of 2008 on District. In DGR in lieu of GR No. 19 of 2008, it is stated that sub-district is part of district that is authorized with duties and functions to implement governmental administration in its territory and to implement duties given by camat.

In Law No. 23 of 2014 and DGR in lieu of GR No. 19 of 2008 on District, it is stated that central government and local government shall conduct sub-district reorganization, by:

1) Creation of sub-district;

2) Elimination and merging of sub-districts;

3) Change of status from administrative village to sub-district;

4) Change of status from sub-district to administrative village.

Creation of sub-district can take form of dividing of one sub-district into two or more sub-districts or merging of division of sub-district from adjacent sub-districts into new sub-district and should at least meet these requirements:

1) Population size;

2) Area size;

3) Part of operational area;

4) Administrative facilities and infrastructures; and

5) Minimum age of sub-district administration by 5 years.

Requirements for creation of sub-district are distinguished by region as follows:

1) Provinces in Java Island.

Requirements for creation of sub-district in Provinces in Java Island consist of:

a) Minimum population size by 8000 (eight thousand) people or 1600 (one thousand and six hundred) heads of household.

b) Minimum area size by $3 \mathrm{Km}^{2}$. 


\section{2) Bali Province}

Requirements for creation of sub-district in Bali Province consist of:

a) Minimum population size by 8000 (eight thousand) people or 1600 (one thousand and six hundred) heads of household.

b) Minimum area size by $3 \mathrm{Km}^{2}$.

3) Provinces in Sumatra Island

Requirements for creation of sub-district in Provinces in Sumatra Island consist of:

a) Minimum population size by 5000 (five thousand) people or 1000 (one thousand) heads of household.

b) Minimum area size by $5 \mathrm{Km}^{2}$.

4) South Sulawesi Province and North Sulawesi Province

Requirements for creation of sub-district in South Sulawesi Province and North Sulawesi Province consist of:

a) Minimum population size by 4000 (four thousand) people or 800 (eight hundred) heads of household.

b) Minimum area size by $5 \mathrm{Km}^{2}$.

5) West Nusa Tenggara Province

Requirements for creation of sub-district in West Nusa Tenggara Province Island consist of:

a) Minimum population size by 3500 (three thousand and five hundred) people or 700 (seven hundred) heads of household.

b) Minimum area size by $7 \mathrm{Km}^{2}$.

6) Central Sulawesi Province, West Sulawesi Province, Southeast Sulawesi Province, Gorontalo Province, and South Kalimantan Province.

Requirements for creation of sub-district in Central Sulawesi Province, West Sulawesi Province, Southeast Sulawesi Province, Gorontalo Province, and South Kalimantan Province consist of:

a) Minimum population size by 2750 (two thousand seventy hundred and fifty) people or 550 (five hundred and fifty) heads of household.

b) Minimum area size by $5 \mathrm{Km}^{2}$.

7) East Kalimantan Province, West Kalimantan Province, Central Kalimantan Province, and North Kalimantan Province.

Requirements for creation of sub-district in East Kalimantan Province, West Kalimantan Province, Central Kalimantan Province, and North Kalimantan consist of:

a) Minimum population size by 2000 (two thousand) people or 400 (four hundred) heads of household.

b) Minimum area size by $7 \mathrm{Km}^{2}$.

8) East Nusa Tenggara Province, Maluku Province, and North Maluku Province.

Requirements for creation of sub-district in East Nusa Tenggara Province, Maluku Province, and North Maluku Province consist of: 
a) Minimum population size by 1500 (one thousand and five hundred) people or 300 (three hundred) heads of household.

b) Minimum area size by $7 \mathrm{Km}^{2}$.

9) Papua Province and West Papua Province.

Requirements for creation of sub-district in Papua Province and West Papua Province consist of:

a) Minimum population size by 1000 (one thousand) people or 200 (two hundred) heads of household;

b) Minimum area size by $7 \mathrm{Km}^{2}$.

Part of operational area is area that is reachable in improving public service and development, and administrative facilities and infrastructures means:

1) Having land for administrative office;

2) Having proper transportation network;

3) Proper communication facilities; and

4) Proper public facilities [4].

In relation with explanation above, Karawang Regency Government is going to study potential of potential area of 2 (two) sub-districts and Hamlets/RWs in West Karawang District, i.e. Karangpawitan Sub-district and Tanjungpura Sub-district, in order to assess and evaluate variables or reliable criteria of regional potential to determine whether or not formation of sub-district can be implemented in both sub-districts.

\section{Problem Statement}

Within the context of formation of new Sub-district in Karawang Regency, the problems can be stated as follows:

1) How is description on capability level of those 2 (two) sub-districts in West Karawang District, i.e. Karangpawitan sub-district and Tanjungpura sub-district, to encourage the success of democratization, development and public service?

2) How is description on public aspiration regarding the plan for formation in 2 (two) sub-districts in West Karawang District, i.e. Karangpawitan sub-district and Tanjungpura sub-district?

3) How is the availability of public services provided by government in those 2 (two) sub-districts in West Karawang District, i.e. Karangpawitan sub-district and Tanjungpura sub-district?

4) How is the quality of public services provided by government in those 2 (two) sub-districts in West Karawang District, i.e. Karangpawitan sub-district and Tanjungpura sub-district?

\section{Theoretical Framework}

The purpose of regional autonomy policy as mentioned in Law No. 32 of 2004 is improvement for better public service and welfare, encouragement of democratic life, justice, and equality, and also preservation of harmony relationship be- 
tween central and local government and inter local governments for integrity of the Unitary State of the Republic of Indonesia. In line with this, regional autonomy is placed entirely for regency/city, and delegation of authority of regional autonomy to regency/city is based on extensive, real and responsible decentralization principle. The achievement of this purpose would be determined by the capability level of villages/Sub-districts as the smallest unit of government which also the nearest to community that provide public services, implement the development and improvement of democracy [5].

Law No. 32 of 2004 Article 227 clause (1) states that sub-district can be formed in district region by local regulation with reference to Government Regulation. GR No. 73 of 2004 on Sub-district furthermore elaborates that formation of new sub-district should consider population size, area size, sociocultural, potential of the sub-district, and administrative facilities and infrastructures. This regulation provides spaces for formation of new sub-district through subdivision of sub-district as long as it is aspired by the public and it shall achieve the purpose of effective administration of government, public services, development and democratization at the smallest unit of government. For this purpose, it is required to measure and evaluate the potential of the sub-district as the basis of whether it is adequate or not for formation of new sub-district [6].

Result of the measurement considers main factor, consisting of accumulation of population size and total number of head of family, and supporting factors comprising particular total score of potential capability level which serve as basis for evaluation of whether or not a sub-district is adequate for formation. Evaluation of potential capability level for division of sub-district is evaluation of potential of the parent sub-district and the plan for formation of sub-district. Result of evaluation can be categorized into 3 (three) levels, qualified/adequate, qualified with condition/fairly adequate and unqualified/inadequate. Result of evaluation serves as recommendation for policy as follows:

1) If proposed parent sub-district and proposed divided sub-district both meet the requirements according to main factor and are qualified/adequate according to supporting factor, the action taken would be recommended for dividing of sub-district or creation of new sub-district;

2) If proposed parent sub-district and proposed divided sub-district meet the requirements according to main factor and are qualified with condition/fairly adequate or unqualified/inadequate according to supporting factor, the action taken would be to recommend for dividing of sub-district or creation of new sub-district, followed by development of potential into qualified/adequate within certain period of time;

3) If any of proposed parent sub-district and proposed formed sub-district fail to meet the requirements according to main factor and is qualified/adequate or qualified with condition/fairly adequate or unqualified/inadequate according to supporting factor, it is not recommended for dividing of sub-district or creation of new Sub-district [7].

For more detail, see chart of theoretical framework (Figure 1): 


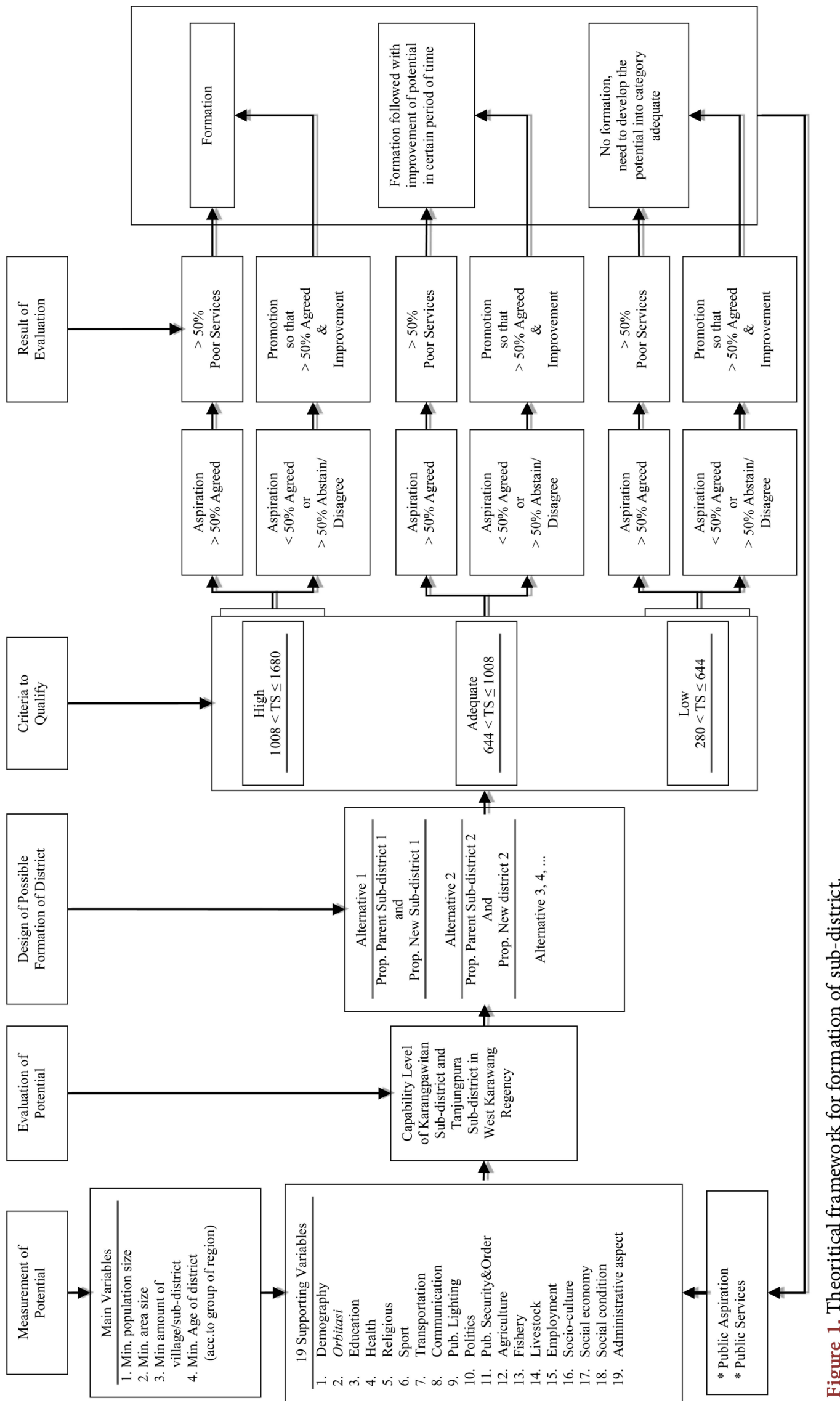




\section{Research Method}

Operational definition of variable for study of development and reorganization of Karangpawitan Sub-district and Tanjungpura Sub-district in West Karawang District, Karawang Regency, is limited according to the scope of development and territorial reorganization with format elaborated in GR No. 129 of 2000 and Government Regulation No. 78 of 2008 in lieu of GR No. 129 of 2000, and Law No. 23 of 2014 and DGR in lieu of GR No. 19 of 2008 on District. Development and reorganization of Karangpawitan Sub-district and Tanjungpura Sub-district in West Karawang District, Karawang Regency uses 19 supporting factors as variable of this study, namely, as shown in Table 2 :

Qualitative data is analyzed by content and depth approach to translate phenomena on 19 supporting variables. How to accommodate the qualitative analysis is by stimulating various inclinations of qualitative responses from respondents on those phenomena. By list of open-end structured questions, complemented with compilation of in-depth interviews and field observation, the variables are compiled into structured file. However, some of the qualitative data are renovated into quantitative data through non-parametric process. Quantitative data is categorized, classified and processed as basis for measurement and analysis to provide clarity and valuation on strength and weakness of the variables [8].

Category for evaluation is based on particular scale and classified into qualified, qualified with condition, and unqualified based on representative total particular score. Each category of evaluation serves as basis for action taken whether or not to implement the formation of village/sub-district and exploitation of its potential.

Evaluation method is determined by distribution method using mean to account for data distribution. Score calculation with this method is adjusted by skewness and kurtosis of data distribution curve. Each sub-indicator has the lowest score of 1 and highest score of 6 . For scoring, the steps are:

1) Calculate mean, standard deviation, and coefficient of kurtosis/skewness.

2) Calculate limit 2 (value $2 \times$ kurtosis/skewness $x$ standard deviation), and limit 1 (value $1 \times$ kurtosis $\times$ standard deviation) and;

3) Determine index class for scoring:

a) If indicator value $>$ mean $+\operatorname{limit} 2$, the score is 6 ;

b) If mean + limit $2 \leq$ indicator value $<$ mean + limit 1 , the score is 5 ;

c) If mean + limit $1 \leq$ indicator value $<$ mean, the score is 4 ;

d) If mean $\leq$ indicator value $<$ mean-limit 1 , the score is 3 ;

e) If mean-limit $1 \leq$ indicator value $<$ mean-limit 2 , the score is 2 ;

f) If indicator value $\leq$ mean-limit 2 , the score is 1 .

Assumption used in valuing is every variable or criteria has distinctive value according to its role and urgency in the administration of government, development and social. Value for basic services such as health and educational facilities are 11, value for social economy, transportation, communication and public 
Table 2. Factors and Indicators of Reorganization of Sub-district.

\begin{tabular}{ll}
\hline NO & \multicolumn{1}{c}{ Factors and Indicators } \\
\hline 1. & Demography \\
& 1) Population Size \\
2) Number of Household \\
3) Area Size. \\
4) Number of Community Unit \\
5) Number of Head of Family \\
6) Population Density
\end{tabular}

2. Orbitasi

1) Traveling distance from RW to Sub-district

2) Traveling time from RW to Sub-district

3. Education

1) Number of educational facilities

2) Illiteracy rate

3) Dropout rate

4) General education graduation rate

5) Index of vocational institutions

4. Health

1) Number of health facilities, medics, infant and child mortality rate

2) Baby and child immunization participation rate

3) Child malnutrition index

4) Ratio of family toilet to household

5) Ratio of pre-prosperous family to population

6) Ratio of drinking water facilities to population

7) Index of house condition

5. Religion

1) Number of religious facilities

6. Sport Facilities

1) Index comparison between sport facilities and population size

7. Transportation

1) Index of transportation facilities

8. Communication

1) Index of communication facilities

9. Public Lighting

1) Number of electricity consumers

2) Number of other public lighting

10. Political Awareness

1) Number of voting rights

2) Number of voters

3) Number of Political Parties 


\section{Continued}

4) Number of NGOs/other society organizations

11. Public Security and Order

1) Number of security facilities

2) Number of security personnel

12. Agriculture

1) Index comparison of area size, yield, and ownership of plantation of non-rice crops, vegetables, fruits and rice fields

2) Number of groups of farmers, irrigation managers, and fice field and plantation facilities

13. Fishery

1) Aquacultural area size

2) Fishery yield and ownership

14. Livestock

1) Large and mid-sized livestock

2) Poultry

15. Employment

1) Number employed population

2) Number of job-seeking population

3) Number of unemployed population

4) Number of large, medium, and small enterprises

5) Number of agricultural companies

\section{Socio-culture}

1) Number of art facilities

2) Number of orphanages

3) Number of tourism facilities

17. Social Economy
1) Shopping facilities
2) Banking Institution
3) Non-Bank Financial Institution

18. Social Condition

1) Number of people with physical disabilities

2) Number of troubled people who become burden of government

19. Administrative Aspect

1) Land and Property Tax

2) Sub-district Own-source Revenue

3) Other Sub-district Revenue

4) Number of Sub-district Apparatus

5) Decision of Sub-district

6) Regulation of Sub-district 
Table 3. Maximum and minimum score of variables.

\begin{tabular}{|c|c|c|c|c|c|c|c|}
\hline No & Variable & $\begin{array}{l}\text { Number of } \\
\text { Indicator }\end{array}$ & Value & $\begin{array}{l}\text { Min } \\
\text { Score }\end{array}$ & $\begin{array}{l}\text { Min } \\
\text { Score }\end{array}$ & $\begin{array}{l}\text { Total } \\
\text { Min } \\
\text { Score }\end{array}$ & $\begin{array}{l}\text { Total } \\
\text { Min } \\
\text { Score }\end{array}$ \\
\hline 1 & DEMOGRAPHY & 3 & 5 & 1 & 6 & 15 & 90 \\
\hline 2 & ORBITASI & 2 & 5 & 1 & 6 & 10 & 60 \\
\hline 3 & EDUCATION & 4 & 11 & 1 & 6 & 44 & 264 \\
\hline 4 & HEALTH & 5 & 11 & 1 & 6 & 55 & 330 \\
\hline 5 & RELIGIOUS & 1 & 3 & 1 & 6 & 3 & 18 \\
\hline 6 & SPORT & 1 & 3 & 1 & 6 & 3 & 18 \\
\hline 7 & TRANSPORTATION & 1 & 7 & 1 & 6 & 7 & 42 \\
\hline 8 & COMMUNICATION & 1 & 7 & 1 & 6 & 7 & 42 \\
\hline 9 & PUBLIC LIGHTING & 2 & 7 & 1 & 6 & 14 & 84 \\
\hline 10 & POLITICAL AWARENESS & 3 & 5 & 1 & 6 & 15 & 90 \\
\hline 11 & PUBLIC SECURITY AND ORDER & 2 & 3 & 1 & 6 & 6 & 36 \\
\hline 12 & AGRICULTURE & 2 & 5 & 1 & 6 & 10 & 60 \\
\hline 13 & FISHERY & 2 & 3 & 1 & 6 & 6 & 36 \\
\hline 14 & LIVESTOCK & 2 & 3 & 1 & 6 & 6 & 36 \\
\hline 15 & EMPLOYMENT & 3 & 3 & 1 & 6 & 9 & 54 \\
\hline 16 & SOCIO-CULTURE & 3 & 5 & 1 & 6 & 15 & 90 \\
\hline 17 & SOCIAL ECONOMY & 3 & 7 & 1 & 6 & 21 & 126 \\
\hline 18 & SOCIAL CONDITION & 2 & 2 & 1 & 6 & 4 & 24 \\
\hline 19 & ADMINISTRATIVE ASPECT & 6 & 5 & 1 & 6 & 30 & 180 \\
\hline \multicolumn{6}{|c|}{ TOTAL } & 280 & 1680 \\
\hline
\end{tabular}

lighting are 7, value for demography, orbitasi, political awareness, agriculture and socio-culture are 5, value for facilities, religious, sport, public security and order, fishery, livestock, and employment are 3 , and value for social condition is 2. Minimum passing score is accumulated total score of sub-indicators in each variable/group of criteria multiplied by score above average for each variable or group of criteria multiplied by value for each group of indicators. Calculation of minimum and maximum total score of each and every variable can be seen in Table 3:

Minimum passing score is accumulated score of sub-indicators in each variable/group of criteria multiplied by score above average for each variable or group of criteria multiplied by value for each group of indicators. Assumption used is score above average for each variable is 3.6. For more detail, see Table 4:

According to table above, the score above average is 1008. It means that a district is declared to be qualified for creation of new district if the score from measurement is equal to or greater than 1008 . On that basis, category for evaluation on potential of district in administration of government, development and 
social can be defined as shown in Table 5:

\section{Result}

Based on field data, results of evaluation and measurement of potential in 2 (two) sub-districts and their RWs in West Karawang District, Karawang Regency are as follows:

1) Formation of Karangpawitan Sub-district

a) Potential of Karangpawitan Sub-district

Table 4. Score above average.

\begin{tabular}{|c|c|c|c|c|c|}
\hline NO & VARIABLE & $\begin{array}{l}\text { NUMBER OF } \\
\text { INDICATOR }\end{array}$ & VALUE & $\begin{array}{c}\text { SCORE ABOVE } \\
\text { AVERAGE }\end{array}$ & $\begin{array}{l}\text { TOTAL } \\
\text { SCORE }\end{array}$ \\
\hline 1 & DEMOGRAPHY & 3 & 5 & 3.6 & 54 \\
\hline 2 & ORBITASI & 2 & 5 & 3.6 & 36 \\
\hline 3 & EDUCATION & 4 & 11 & 3.6 & 158 \\
\hline 4 & HEALTH & 5 & 11 & 3.6 & 198 \\
\hline 5 & RELIGIOUS & 1 & 3 & 3.6 & 11 \\
\hline 6 & SPORT & 1 & 3 & 3.6 & 11 \\
\hline 7 & TRANSPORTATION & 1 & 7 & 3.6 & 25 \\
\hline 8 & COMMUNICATION & 1 & 7 & 3.6 & 25 \\
\hline 9 & PUBLIC LIGHTING & 2 & 7 & 3.6 & 50 \\
\hline 10 & POLITICAL AWARENESS & 3 & 5 & 3.6 & 54 \\
\hline 11 & PUBLIC SECURITY AND ORDER & 2 & 3 & 3.6 & 22 \\
\hline 12 & AGRICULTURE & 2 & 5 & 3.6 & 36 \\
\hline 13 & FISHERY & 2 & 3 & 3.6 & 22 \\
\hline 14 & LIVESTOCK & 2 & 3 & 3.6 & 22 \\
\hline 15 & EMPLOYMENT & 3 & 3 & 3.6 & 32 \\
\hline 16 & SOCIO-CULTURE & 3 & 5 & 3.6 & 54 \\
\hline 17 & SOCIAL ECONOMY & 3 & 7 & 3.6 & 76 \\
\hline 18 & SOCIAL CONDITION & 2 & 2 & 3.6 & 14 \\
\hline 19 & ADMINISTRATIVE ASPECT & 6 & 5 & 3.6 & 108 \\
\hline \multicolumn{5}{|c|}{ TOTAL } & 1008 \\
\hline
\end{tabular}

Table 5. Category of action taken.

\begin{tabular}{|c|c|c|c|}
\hline NO & CATEGORY & $\begin{array}{l}\text { INTERVAL OF } \\
\text { TOTAL SCORE }\end{array}$ & CONCLUSION \\
\hline 1 & High Potential & $1008 \leq \mathrm{TS}<1680$ & Adequate for formation \\
\hline 2 & Adequate Potential & $644 \leq \mathrm{TS}<1008$ & $\begin{array}{c}\text { Fairly adequate for formation followed by } \\
\text { development of potential within certain period of time }\end{array}$ \\
\hline 3 & Low Potential & $280 \leq \mathrm{TS}<644$ & $\begin{array}{l}\text { Inadequate for formation, require development of } \\
\text { potential into category of Fairly adequate }\end{array}$ \\
\hline
\end{tabular}


Result of study on potential of Karangpawitan Sub-district by scoring the 19 (nineteen) variables towards all RWs in Karangpawitan Sub-district resulted in total score of 1042 or $98.9 \%$ of minimum standard for passing category (1008), as shown in Table 6:

Based on data above, potential of Karangpawitan Sub-district has score of 1042 (98.9\%) of minimum passing standard, or potential of Karangpawitan Sub-district has score greater than $1008(1008 \leq 1042<1680)$ meaning than it is adequate for formation.

b) Potential of RWs and Mapping of RWs in Karangpawitan Sub-district

Potential of RWs in Karangpawitan Sub-district based on result of study on potential of Karangpawitan Sub-district by scoring on 19 (nineteen) variables (attached), with category of proper, fairly adequate or inadequate for formation are shown in Table 7:

Based on result of analysis above, mapping of RWs in Karangpawitan Sub-district, there are 15 (fifteen) RWs in category of adequate for formation and 10 (ten) RWs in category of fairly adequate for formation, and more detail

Table 6. Potential of Karangpawitan Sub-district.

\begin{tabular}{|c|c|c|c|c|}
\hline NO & VARIABLE & $\begin{array}{l}\text { STANDARD } \\
\text { SCORE }\end{array}$ & $\begin{array}{c}\text { SCORE OF } \\
\text { KARANGPAWITAN } \\
\text { SUB-DISTRICT }\end{array}$ & $\%$ \\
\hline 1 & DEMOGRAPHY & 54 & 59 & 108.9 \\
\hline 2 & ORBITASI & 36 & 38 & 105.0 \\
\hline 3 & EDUCATION & 158 & 194 & 122.8 \\
\hline 4 & HEALTH & 198 & 186 & 94.0 \\
\hline 5 & RELIGIOUS & 11 & 10 & 94.9 \\
\hline 6 & SPORT & 11 & 10 & 90.5 \\
\hline 7 & TRANSPORTATION & 25 & 25 & 98.6 \\
\hline 8 & COMMUNICATION & 25 & 25 & 98.6 \\
\hline 9 & PUBLIC LIGHTING & 50 & 47 & 94.1 \\
\hline 10 & POLITICAL AWARENESS & 54 & 61 & 113.7 \\
\hline 11 & PUBLIC SECURITY AND ORDER & 22 & 20 & 91.6 \\
\hline 12 & AGRICULTURE & 36 & 32 & 87.8 \\
\hline 13 & FISHERY & 22 & 18 & 82.9 \\
\hline 14 & LIVESTOCK & 22 & 20 & 90.0 \\
\hline 15 & EMPLOYMENT & 32 & 31 & 96.4 \\
\hline 16 & SOCIO-CULTURE & 54 & 48 & 88.9 \\
\hline 17 & SOCIAL ECONOMY & 76 & 66 & 86.9 \\
\hline 18 & SOCIAL CONDITION & 14 & 15 & 106.9 \\
\hline \multirow[t]{2}{*}{19} & ADMINISTRATIVE ASPECT & 108 & 138 & 127.4 \\
\hline & TOTAL \& MEAN & 1008 & 1042 & 98.9 \\
\hline
\end{tabular}

Source: Data Processing, 2017. 
Table 7. Potential RWs in Karangpawitan Sub-district.

\begin{tabular}{|c|c|c|c|c|c|}
\hline NO & SUB-DISTRICT & RW & TOTAL SCORE & SCORE INTERVAL & CATEGORY \\
\hline 1 & & RW 01 & 1142 & $1008 \leq \mathrm{TS}<1680$ & Adequate \\
\hline 2 & & RW 02 & 1005 & $644 \leq \mathrm{TS}<1008$ & Fairly Adequate \\
\hline 3 & & RW 03 & 1046 & $1008 \leq$ TS $<1680$ & Adequate \\
\hline 4 & & RW 04 & 1173 & $1008 \leq \mathrm{TS}<1680$ & Adequate \\
\hline 5 & & RW 05 & 1044 & $1008 \leq$ TS $<1680$ & Adequate \\
\hline 6 & & RW 06 & 1057 & $1008 \leq$ TS $<1680$ & Adequate \\
\hline 7 & & RW 07 & 988 & $644 \leq \mathrm{TS}<1008$ & Fairly Adequate \\
\hline 8 & & RW 08 & 1005 & $644 \leq \mathrm{TS}<1008$ & Fairly Adequate \\
\hline 9 & & RW 09 & 1020 & $1008 \leq$ TS $<1680$ & Adequate \\
\hline 10 & & RW 10 & 983 & $644 \leq \mathrm{TS}<1008$ & Fairly Adequate \\
\hline 11 & & RW 11 & 980 & $644 \leq \mathrm{TS}<1008$ & Fairly Adequate \\
\hline 12 & & RW 12 & 1002 & $644 \leq \mathrm{TS}<1008$ & Fairly Adequate \\
\hline 13 & Karangpawitan & RW 13 & 1142 & $1008 \leq \mathrm{TS}<1680$ & Adequate \\
\hline 14 & & RW 14 & 1002 & $644 \leq \mathrm{TS}<1008$ & Fairly Adequate \\
\hline 15 & & RW 15 & 1061 & $1008 \leq \mathrm{TS}<1680$ & Adequate \\
\hline 16 & & RW 16 & 999 & $644 \leq \mathrm{TS}<1008$ & Fairly Adequate \\
\hline 17 & & RW 17 & 1134 & $1008 \leq \mathrm{TS}<1680$ & Adequate \\
\hline 18 & & RW 18 & 1009 & $1008 \leq \mathrm{TS}<1680$ & Adequate \\
\hline 19 & & RW 19 & 1055 & $1008 \leq \mathrm{TS}<1680$ & Adequate \\
\hline 20 & & RW 20 & 1002 & $644 \leq \mathrm{TS}<1008$ & Fairly Adequate \\
\hline 21 & & RW 21 & 1002 & $644 \leq \mathrm{TS}<1008$ & Fairly Adequate \\
\hline 22 & & RW 22 & 1056 & $1008 \leq \mathrm{TS}<1680$ & Adequate \\
\hline 23 & & RW 23 & 1047 & $1008 \leq \mathrm{TS}<1680$ & Adequate \\
\hline 24 & & RW 24 & 1050 & $1008 \leq \mathrm{TS}<1680$ & Adequate \\
\hline \multirow[t]{3}{*}{25} & & RW 25 & 1050 & $1008 \leq \mathrm{TS}<1680$ & Adequate \\
\hline & TOTAL & & 26,054 & & \\
\hline & AVERAGE & & 1042 & & \\
\hline \multicolumn{3}{|c|}{ TOTAL MINIMUM SCORE } & 980 & & \\
\hline \multicolumn{3}{|c|}{ TOTAL MAXIMUM SCORE } & 1173 & & \\
\hline
\end{tabular}

Source: Data Processing, 2017.

on the result of mapping is shown in Table 8:

RW in Karangpawitan Sub-district with minimum score is RW 11 by 980 . And RW with maximum score is RW 04 by 1173. Difference of potential of RWs in Karangpawitan Sub-district between the highest and the lowest score is 193 or $20 \%$ of the lowest potential of RW. More complete comparison of potential per RW in Karangpawitan Sub-district between the highest and the lowest potential is shown in Table 9: 
Table 8. Mapping of RWs in Karangpawitan Sub-district.

\begin{tabular}{|c|c|c|}
\hline NO & $\begin{array}{l}\text { NOMINATED SUB-DISTRICT FAIRLY } \\
\text { ADEQUATE FOR FORMATION }\end{array}$ & $\begin{array}{l}\text { NOMINATED SUB-DISTRICT } \\
\text { ADEQUATE FOR FORMATION }\end{array}$ \\
\hline 1 & RW 02 & RW 01 \\
\hline 2 & RW 07 & RW 03 \\
\hline 3 & RW 08 & RW 04 \\
\hline 4 & RW 10 & RW 05 \\
\hline 5 & RW 11 & RW 06 \\
\hline 6 & RW 12 & RW 09 \\
\hline 7 & RW 14 & RW 13 \\
\hline 8 & RW 16 & RW 15 \\
\hline 9 & RW 20 & RW 17 \\
\hline 10 & RW 21 & RW 18 \\
\hline 11 & & RW 19 \\
\hline 12 & & RW 22 \\
\hline 13 & & RW 23 \\
\hline 14 & & RW 24 \\
\hline 15 & & RW 25 \\
\hline
\end{tabular}

Source: Data Processing, 2017.

Table 9. Comparison of Potential of RWs in Karangpawitan Sub-district.

\begin{tabular}{|c|c|c|c|c|c|c|}
\hline NO & SUB-DISTRICT & RW & $\begin{array}{l}\text { TOTAL } \\
\text { SCORE }\end{array}$ & DIFFERENCE & PERCENTAGE & $\begin{array}{l}\text { NOMINATED } \\
\text { VILLAGE }\end{array}$ \\
\hline 1 & & RW 01 & 1142 & 162 & 17 & 2 \\
\hline 2 & & RW 02 & 1005 & 25 & 3 & 1 \\
\hline 3 & & RW 03 & 1046 & 66 & 7 & 2 \\
\hline 4 & & RW 04 & 1173 & 193 & 20 & 2 \\
\hline 5 & & RW 05 & 1044 & 64 & 7 & 2 \\
\hline 6 & & RW 06 & 1057 & 77 & 8 & 2 \\
\hline 7 & & RW 07 & 988 & 8 & 1 & 1 \\
\hline 8 & & RW 08 & 1005 & 25 & 3 & 1 \\
\hline 9 & Karangpawitan & RW 09 & 1020 & 40 & 4 & 2 \\
\hline 10 & & RW 10 & 983 & 3 & 0 & 1 \\
\hline 11 & & RW 11 & 980 & 0 & 0 & 1 \\
\hline 12 & & RW 12 & 1002 & 22 & 2 & 1 \\
\hline 13 & & RW 13 & 1142 & 162 & 17 & 2 \\
\hline 14 & & RW 14 & 1002 & 22 & 2 & 1 \\
\hline 15 & & RW 15 & 1061 & 81 & 8 & 2 \\
\hline 16 & & RW 16 & 999 & 19 & 2 & 1 \\
\hline
\end{tabular}




\section{Continued}

\begin{tabular}{llllll}
\hline 17 & RW 17 & 1134 & 154 & 16 & 2 \\
18 & RW 18 & 1009 & 29 & 3 & 2 \\
19 & RW 19 & 1055 & 75 & 8 & 2 \\
20 & RW 20 & 1002 & 22 & 2 & 1 \\
21 & RW 21 & 1002 & 22 & 2 & 1 \\
22 & RW 22 & 1056 & 76 & 8 & 2 \\
23 & RW 23 & 1047 & 67 & 7 & 2 \\
24 & RW 24 & 1050 & 70 & 7 & 2 \\
25 & RW 25 & 1050 & 70 & 7 & 2 \\
& Total Formation & & 40
\end{tabular}

Source: Data processing, 2017

Table 10. Mapping of RWs in Karangpawitan Sub-district (Alternative 1).

\begin{tabular}{|c|c|c|c|c|c|c|}
\hline NO & $\begin{array}{c}\text { FORMED } \\
\text { SUB-DISTRICT }\end{array}$ & $\begin{array}{c}\text { Nominated } \\
\text { RW }\end{array}$ & $\begin{array}{l}\text { Total } \\
\text { Score }\end{array}$ & $\begin{array}{c}\text { PARENT } \\
\text { SUB-DISTRICT }\end{array}$ & $\begin{array}{c}\text { Nominated } \\
\text { RW }\end{array}$ & $\begin{array}{l}\text { Total } \\
\text { Score }\end{array}$ \\
\hline 1 & & RW 03 & 1046 & & RW 02 & 1005 \\
\hline 2 & & RW 14 & 1002 & & RW 01 & 1142 \\
\hline 3 & & RW 15 & 1061 & & RW 12 & 1002 \\
\hline 4 & & RW 16 & 999 & & RW 13 & 1142 \\
\hline 5 & & RW 17 & 1134 & & RW 04 & 1173 \\
\hline 6 & & RW 18 & 1009 & & RW 05 & 1044 \\
\hline 7 & & RW 24 & 1050 & & RW 06 & 1057 \\
\hline 8 & & RW 19 & 1055 & & RW 07 & 988 \\
\hline 9 & & RW 20 & 1002 & & RW 08 & 1005 \\
\hline 10 & & RW 21 & 1002 & & RW 09 & 1020 \\
\hline 11 & & RW 22 & 1056 & & RW 10 & 983 \\
\hline 12 & & RW 23 & 1047 & & RW 11 & 980 \\
\hline \multirow[t]{5}{*}{13} & & RW 25 & 1050 & & & \\
\hline & TOTAL & & 13,513 & & & 12,541 \\
\hline & AVERAGE & & 1039 & & & 1045 \\
\hline & TOTAL MINIMUM & SCORE & 999 & & & 980 \\
\hline & TOTAL MAXIMUM & SCORE & 1134 & & & 1173 \\
\hline
\end{tabular}

Source: Data Processing, 2017

Based on table above, the result shows that from 25 (twenty five) RWs in Karangpawitan Sub-district, 40 (fourty) nominated RWs can be formed if formation to be implemented. RWs that are adequate and have better potential for formation are: RW01, RW 03, RW 04, RW 05, RW 06, RW 09, RW 13, RW 15, RW 17, RW 18, RW 19, RW 22, RW 23, RW 24 and RW 25. Next, based on re- 
sult of analysis of potential of RWs above, there are 3 (three) alternatives for formation of Karangpawitan Sub-district with mapping of each RW as Table 10:

Mapping of RWs in Karangpawitan Sub-district in alternative 1 is formed sub-district with nominated RWs: RW 03, RW 14, RW 15, RW 16, RW 17, RW 18, RW 24, RW 19, RW 20, RW 21, RW 22, RW 23 and RW 25. Parent sub-district with nominated RWs: RW 02, RW 01, RW 12, RW 13, RW 04, RW 05, RW 06, RW 07, RW 08, RW 09, RW 10, and RW 11.

\section{2) Formation of Karangpawitan Sub-district Alternative 2}

As shown in Table 11, mapping of RWs in Karangpawitan Sub-district in alternative 2 is formed sub-district 1 with nominated RWs: RW03, RW 14, RW 15, RW 16, RW 17, RW 18 and RW 24. Formed sub-district 2 with nominated RWs: RW 19, RW 20, RW 21, RW 22, RW 23 and RW 25. Parent sub-district with nominated RWs: RW02, RW 01, RW 12, RW 13, RW 04, RW 05, RW 06, RW 07, RW 08, RW 09, RW 10, and RW 11.

\section{3) Formation of Karangpawitan Sub-district Alternative 3}

As shown in Table 12, mapping of RWs in Karangpawitan Sub-district in alternative 3 is formed sub-district 1 with nominated RWs: RW 05, RW 06, RW 07, RW 08, RW 09, RW 10 and RW 11. Formed sub-district 2 with nominated RWs: RW 03, RW 14, RW 15, RW 16, RW 17, RW 18 and RW 24. Formed sub-district 3

Table 11. Mapping of RWs in Karangpawitan Sub-district (Alternative 2).

\begin{tabular}{|c|c|c|c|c|c|c|c|c|c|}
\hline NO & $\begin{array}{c}\text { FORMED } \\
\text { SUB-DISTRICT } 1\end{array}$ & Nominated RW & $\begin{array}{l}\text { Score } \\
\text { Total }\end{array}$ & $\begin{array}{c}\text { FORMED } \\
\text { SUB-DISTRICT } 2\end{array}$ & Nominated RW & $\begin{array}{l}\text { Score } \\
\text { Total }\end{array}$ & $\begin{array}{c}\text { PARENT } \\
\text { SUB-DISTRICT }\end{array}$ & Nominated RW & $\begin{array}{l}\text { Score } \\
\text { Total }\end{array}$ \\
\hline 1 & & RW 03 & 1046 & & RW 19 & 1055 & & RW 02 & 1005 \\
\hline 2 & & RW 14 & 1002 & & RW 20 & 1002 & & RW 01 & 1142 \\
\hline 3 & & RW 15 & 1061 & & RW 21 & 1002 & & RW 12 & 1002 \\
\hline 4 & & RW 16 & 999 & & RW 22 & 1056 & & RW 13 & 1142 \\
\hline 5 & & RW 17 & 1134 & & RW 23 & 1047 & & RW 04 & 1173 \\
\hline 6 & & RW 18 & 1009 & & RW 25 & 1050 & & RW 05 & 1044 \\
\hline 7 & & RW 24 & 1050 & & & & & RW 06 & 1057 \\
\hline 8 & & & & & & & & RW 07 & 988 \\
\hline 9 & & & & & & & & RW 08 & 1005 \\
\hline 10 & & & & & & & & RW 09 & 1020 \\
\hline 11 & & & & & & & & RW 10 & 983 \\
\hline 12 & & & & & & & & RW 11 & 980 \\
\hline \multicolumn{3}{|c|}{ TOTAL } & 7301 & & & 6212 & & & 12,541 \\
\hline \multicolumn{3}{|c|}{ AVERAGE } & 1043 & & & 1035 & & & 1045 \\
\hline \multicolumn{3}{|c|}{ TOTAL MINIMUM SCORE } & 999 & & & 1002 & & & 980 \\
\hline \multicolumn{3}{|c|}{ TOTAL MAXIMUM SCORE } & 1134 & & & 1056 & & & 1173 \\
\hline
\end{tabular}

Source: Data Processing, 2017. 
Table 12. Mapping of RWs in Karangpawitan Sub-district (Alternative 3).

\begin{tabular}{|c|c|c|c|c|c|c|c|c|c|c|c|c|}
\hline NO & $\begin{array}{c}\text { FORMED } \\
\text { SUB-DISTRICT } \\
1\end{array}$ & $\begin{array}{c}\text { Nominate } \\
\text { d RW }\end{array}$ & $\begin{array}{l}\text { Total } \\
\text { Score }\end{array}$ & $\begin{array}{c}\text { FORMED } \\
\text { SUB-DISTRIC } \\
\text { T } 2\end{array}$ & $\begin{array}{c}\text { Nominate } \\
\text { d RW }\end{array}$ & $\begin{array}{l}\text { Total } \\
\text { Score }\end{array}$ & $\begin{array}{c}\text { FORMED } \\
\text { SUB-DISTRICT } \\
3\end{array}$ & $\begin{array}{c}\text { Nominated } \\
\text { RW }\end{array}$ & $\begin{array}{l}\text { Total } \\
\text { Score }\end{array}$ & $\begin{array}{c}\text { PARENT } \\
\text { SUB-DISTRICT }\end{array}$ & $\begin{array}{c}\text { Nominated } \\
\text { RW }\end{array}$ & $\begin{array}{l}\text { Total } \\
\text { Score }\end{array}$ \\
\hline 1 & & RW 05 & 1044 & & RW 03 & 1046 & & RW 19 & 1055 & & RW 02 & 1005 \\
\hline 2 & & RW 06 & 1057 & & RW 14 & 1002 & & RW 20 & 1002 & & RW 01 & 1142 \\
\hline 3 & & RW 07 & 988 & & RW 15 & 1061 & & RW 21 & 1002 & & RW 12 & 1002 \\
\hline 4 & & RW 08 & 1005 & & RW 16 & 999 & & RW 22 & 1056 & & RW 13 & 1142 \\
\hline 5 & & RW 09 & 1020 & & RW 17 & 1134 & & RW 23 & 1047 & & RW 04 & 1173 \\
\hline 6 & & RW 10 & 983 & & RW 18 & 1009 & & RW 25 & 1050 & & & \\
\hline \multirow[t]{3}{*}{7} & & RW 11 & 980 & & RW 24 & 1050 & & & & & & \\
\hline & \multicolumn{2}{|l|}{ TOTAL } & 7077 & & & 7301 & & & 6212 & & & 5464 \\
\hline & \multicolumn{2}{|l|}{ AVERAGE } & 1011 & & & 1043 & & & 1035 & & & 1093 \\
\hline \multicolumn{3}{|c|}{ TOTAL MINIMUM SCORE } & 980 & & & 999 & & & 1002 & & & 1002 \\
\hline \multicolumn{3}{|c|}{ TOTAL MAXIMUM SCORE } & 1057 & & & 1134 & & & 1056 & & & 1173 \\
\hline
\end{tabular}

Source: Data Processing, 2017.

Table 13. Mapping of RWs in Karangpawitan Sub-district.

\begin{tabular}{cccccc}
\hline \multirow{2}{*}{ Mapping } & \multicolumn{3}{c}{ Average Score } & & Difference \\
\cline { 2 - 4 } & Parent Sub-district & Formed Sub-district 1 & Formed Sub-district 2 & Formed Sub-district 3 & 6 \\
\hline Alternative 1 & 1045 & 1039 & & & 2 \\
Alternative 2 & 1045 & 1043 & & 1035 & 10 \\
& & & & 1035 & 82 \\
Alternative 3 & 1093 & 1011 & & 50 & 57 \\
\hline
\end{tabular}

Source: Data Processing, 2017.

with nominated RWs: RW 19, RW 20, RW 21, RW 22, RW 23 and RW 25. Parent sub-district with nominated RWs: RW 02, RW 01, RW 12, RW 13, RW 04.

Based on comparison of potential as shown in Table 13, it can be explained that in alternative 1 , comparison between proposed parent sub-district and proposed formed sub-district is by 6 , which means that proposed parent sub-district has lower potential than proposed formed sub-district. In alternative 2, comparison between proposed parent sub-district and proposed formed sub-district 1 and proposed formed sub-district 2 is by 2 and 10 respectively, which means that proposed parent sub-district has lower potential than proposed formed sub-districts. In alternative 3, comparison between proposed parent sub-district and proposed formed sub-district 1, proposed formed sub-district 2 and proposed formed sub-district 3 are by 82,50 and 57 respectively. Therefore, it is 
clear that alternative 1 is decided to be choice 1 . This is based on consideration that formation according to division of governmental operational area is relatively more balanced in terms of potential than formation by alternative 1 regarding the 19 variables. Difference between proposed parent sub-district and proposed formed sub-district in alternative 1 is only 6.

4) Formation of Tanjungpura Sub-district

\section{a) Potential of Tanjungpura Sub-district}

Result of study on potential of Tanjungpura Sub-district by scoring the 19 (nineteen) variables towards all RWs in Tanjungpura Sub-district resulted in total score of 1011 or $96.4 \%$ of minimum standard for passing category (1008), as shown in Table 14:

Based on data above, potential of Tanjungpura Sub-district has score of 1011 (96.4\%) of minimum passing standard, or potential of Tanjungpura Sub-district has score greater than $1008(1008 \leq 1011<1680)$ meaning than it is adequate for formation.

Table 14. Potential of Tanjungpura Sub-district.

\begin{tabular}{|c|c|c|c|c|}
\hline NO & VARIABLE & $\begin{array}{l}\text { STANDARD } \\
\text { SCORE }\end{array}$ & $\begin{array}{c}\text { SCORE OF } \\
\text { TANJUNGPURA } \\
\text { SUB-DISTRICT }\end{array}$ & $\%$ \\
\hline 1 & 2 & 3 & 4 & 5 \\
\hline 1 & DEMOGRAPHY & 54 & 52 & 96.1 \\
\hline 2 & ORBITASI & 36 & 30 & 82.5 \\
\hline 3 & EDUCATION & 158 & 152 & 96.2 \\
\hline 4 & HEALTH & 198 & 213 & 107.6 \\
\hline 5 & RELIGIOUS & 11 & 11 & 98.9 \\
\hline 6 & SPORT & 11 & 10 & 92.0 \\
\hline 7 & TRANSPORTATION & 25 & 25 & 101.5 \\
\hline 8 & COMMUNICATION & 25 & 25 & 98.0 \\
\hline 9 & PUBLIC LIGHTING & 50 & 46 & 91.0 \\
\hline 10 & POLITICAL AWARENESS & 54 & 51 & 93.8 \\
\hline 11 & PUBLIC SECURITY AND ORDER & 22 & 20 & 90.3 \\
\hline 12 & AGRICULTURE & 36 & 31 & 85.1 \\
\hline 13 & FISHERY & 22 & 18 & 83.5 \\
\hline 14 & LIVESTOCK & 22 & 19 & 86.9 \\
\hline 15 & EMPLOYMENT & 32 & 33 & 104.3 \\
\hline 16 & SOCIO-CULTURE & 54 & 49 & 91.4 \\
\hline 17 & SOCIAL ECONOMY & 76 & 72 & 94.4 \\
\hline 18 & SOCIAL CONDITION & 14 & 15 & 109.8 \\
\hline \multirow[t]{2}{*}{19} & ADMINISTRATIVE ASPECT & 108 & 139 & 129.1 \\
\hline & TOTAL \& MEAN & 1008 & 1011 & 96.4 \\
\hline
\end{tabular}

Source: Data Processing, 2017 


\section{b) Potential of RWs and Mapping of RWs in Tanjungpura Sub-district}

Potential of RWs in Tanjungpura Sub-district based on result of study on potential of Tanjungpura Sub-district by scoring on 19 (nineteen) variables (attached), with category of proper, fairly adequate or inadequate for formation are shown in Table 15:

Based on result of analysis above, mapping of RWs in Tanjungpura Sub-district, there are 9 (nine) RWs in category of adequate for formation and 7 (seven) RWs in category of fairly adequate for formation, and more detail on the result of mapping is shown in Table 16:

RW in Tanjungpura Sub-district with minimum score is RW 05 by 902 . And RW with maximum score is RW 15 by 1210 . Difference of potential of RWs in Tanjungpura Sub-district between the highest and the lowest score is 308 or $34 \%$ of the lowest potential of RW. More complete comparison of potential per RW in Tanjungpura Sub-district between the highest and the lowest potential is shown in Table 17:

RW in Tanjungpura Sub-district with potential of equal to or greater than the lowest regional potential of district by $30 \%$ can be said as having great potential for formation. Based on table above, the result shows that from 16 (sixteen) RWs

Table 15. Potential RWs in Karangpawitan Sub-district.

\begin{tabular}{|c|c|c|c|c|c|}
\hline NO & SUB-DISTRICT & RW & TOTAL SCORE & SCORE INTERVAL & CATEGORY \\
\hline 2 & & RW 02 & 1129 & $1008 \leq \mathrm{TS}<1680$ & Adequate \\
\hline 3 & & RW 03 & 902 & $644 \leq \mathrm{TS}<1008$ & Fairly Adequate \\
\hline 4 & & RW 04 & 1106 & $1008 \leq \mathrm{TS}<1680$ & Adequate \\
\hline 5 & & RW 05 & 902 & $644 \leq \mathrm{TS}<1008$ & Fairly Adequate \\
\hline 6 & & RW 06 & 917 & $644 \leq \mathrm{TS}<1008$ & Fairly Adequate \\
\hline 7 & & RW 07 & 902 & $644 \leq \mathrm{TS}<1008$ & Fairly Adequate \\
\hline 8 & & RW 08 & 987 & $644 \leq \mathrm{TS}<1008$ & Fairly Adequate \\
\hline 9 & & RW 09 & 1088 & $1008 \leq \mathrm{TS}<1680$ & Adequate \\
\hline 10 & & RW 10 & 1018 & $1008 \leq \mathrm{TS}<1680$ & Adequate \\
\hline 11 & & RW 11 & 1011 & $1008 \leq \mathrm{TS}<1680$ & Adequate \\
\hline 12 & & RW 12 & 1009 & $1008 \leq \mathrm{TS}<1680$ & Adequate \\
\hline 13 & & RW 13 & 917 & $644 \leq \mathrm{TS}<1008$ & Fairly Adequate \\
\hline 14 & & RW 14 & 1159 & $1008 \leq \mathrm{TS}<1680$ & Adequate \\
\hline 15 & & RW 15 & 1210 & $1008 \leq \mathrm{TS}<1680$ & Adequate \\
\hline \multirow[t]{3}{*}{16} & & RW 16 & 1015 & $1008 \leq \mathrm{TS}<1680$ & Adequate \\
\hline & TOTAL & & 16,174 & & \\
\hline & AVERAGE & & 1011 & & \\
\hline \multicolumn{3}{|c|}{ TOTAL MINIMUM SCORE } & 902 & & \\
\hline \multicolumn{3}{|c|}{ TOTAL MAXIMUM SCORE } & 1210 & & \\
\hline
\end{tabular}

Source: Data Processing, 2017. 
Table 16. Mapping of RWs in Tanjungpura Sub-distric.

\begin{tabular}{lcc}
\hline NO & $\begin{array}{c}\text { NOMINATED SUB-DISTRICT FAIRLY } \\
\text { ADEQUATE FOR FORMATION }\end{array}$ & $\begin{array}{c}\text { NOMINATED SUB-DISTRICT FAIRLY } \\
\text { ADEQUATE FOR FORMATION }\end{array}$ \\
\hline 1 & RW 01 & RW 02 \\
2 & RW 03 & RW 04 \\
3 & RW 05 & RW 09 \\
4 & RW 06 & RW 10 \\
5 & RW 07 & RW 11 \\
6 & RW 08 & RW 12 \\
7 & RW 13 & RW 14 \\
8 & & RW 15 \\
9 & & RW 16 \\
\hline
\end{tabular}

Source: Data Processing, 2017.

Table 17. Comparison of Potential of RWs in Tanjungpura Sub-district.

\begin{tabular}{|c|c|c|c|c|c|c|}
\hline NO & SUB-DISTRICT & RW & $\begin{array}{l}\text { SCORE } \\
\text { TOTAL }\end{array}$ & DIFFERENCE & $\%$ & $\begin{array}{l}\text { NOMINATED } \\
\text { VILLAGE }\end{array}$ \\
\hline 1 & & RW 01 & 902 & 0 & 0 & 1 \\
\hline 2 & & RW 02 & 1129 & 227 & 25 & 2 \\
\hline 3 & & RW 03 & 902 & 0 & 0 & 1 \\
\hline 4 & & RW 04 & 1106 & 204 & 23 & 2 \\
\hline 5 & & RW 05 & 902 & 0 & 0 & 1 \\
\hline 6 & & RW 06 & 917 & 15 & 2 & 1 \\
\hline 7 & & RW 07 & 902 & 0 & 0 & 1 \\
\hline 8 & & RW 08 & 987 & 85 & 9 & 1 \\
\hline 9 & 1 anjuigpuia & RW 09 & 1088 & 186 & 21 & 2 \\
\hline 10 & & RW 10 & 1018 & 116 & 13 & 2 \\
\hline 11 & & RW 11 & 1011 & 109 & 12 & 2 \\
\hline 12 & & RW 12 & 1009 & 107 & 12 & 2 \\
\hline 13 & & RW 13 & 917 & 15 & 2 & 1 \\
\hline 14 & & RW 14 & 1159 & 257 & 28 & 2 \\
\hline 15 & & RW 15 & 1210 & 308 & 34 & 2 \\
\hline 16 & & RW 16 & 1015 & 113 & 13 & 2 \\
\hline \multicolumn{6}{|c|}{ Total Formation } & 25 \\
\hline
\end{tabular}

Source: Data Processing, 2017.

in Tanjungpura Sub-district, 25 (twenty five) nominated RWs can be formed if formation to be implemented. RWs that are adequate and have better potential for formation are: RW 02, RW 04, RW 09, RW 10, RW 11, RW 12, RW 14, RW 15 and RW 16. Next, based on result of analysis of potential of RWs above, there 
are 2 (two) alternatives for formation of Tanjungpura Sub-district with mapping of each RW in Table 18:

1) Formation of Tanjungpura Sub-district Alternative 1

Mapping of RWs in Tanjungpura Sub-district in alternative 1 is formed sub-district with nominated RWs: RW 03, RW 14, RW 15, RW 07, RW 08, RW 09, RW 10, RW 11, RW 12, RW 13, RW 14, RW 15 and RW 16. Formed sub-district 2

Table 18. Mapping of RWs in Tanjungpura Sub-district (Alternative 1).

\begin{tabular}{|c|c|c|c|c|c|c|}
\hline NO & $\begin{array}{c}\text { FORMED } \\
\text { SUB-DISTRICT }\end{array}$ & $\begin{array}{c}\text { Nominated } \\
\text { RW }\end{array}$ & Total Score & $\begin{array}{c}\text { PARENT } \\
\text { SUB-DISTRICT }\end{array}$ & $\begin{array}{c}\text { Nominated } \\
\text { RW }\end{array}$ & Total Score \\
\hline 1 & & RW 07 & 902 & & RW 01 & 902 \\
\hline 2 & & RW 08 & 987 & & RW 02 & 1129 \\
\hline 3 & & RW 09 & 1088 & & RW 03 & 902 \\
\hline 4 & & RW 10 & 1018 & & RW 04 & 1106 \\
\hline 5 & & RW 11 & 1011 & & RW 05 & 902 \\
\hline 6 & & RW 12 & 1009 & & RW 06 & 917 \\
\hline 7 & & RW 13 & 917 & & & \\
\hline 8 & & RW 14 & 1159 & & & \\
\hline 9 & & RW 15 & 1210 & & & \\
\hline 10 & & RW 16 & 1015 & & & \\
\hline \multicolumn{3}{|c|}{ TOTAL } & 10,316 & & & 5858 \\
\hline \multicolumn{3}{|c|}{ AVERAGE } & 1032 & & & 976 \\
\hline \multicolumn{3}{|c|}{ TOTAL MINIMUM SCORE } & 902 & & & 902 \\
\hline \multicolumn{3}{|c|}{ TOTAL MAXIMUM SCORE } & 1210 & & & 1129 \\
\hline
\end{tabular}

Source: Data Processing, 2017

Table 19. Mapping of RWs in Tanjungpura Sub-district (Alternative 2).

\begin{tabular}{|c|c|c|c|c|c|c|c|c|c|}
\hline NO & $\begin{array}{c}\text { FORMED } \\
\text { SUB-ISTRICT } 1\end{array}$ & $\begin{array}{l}\text { Nominated } \\
\text { RW }\end{array}$ & $\begin{array}{l}\text { Total } \\
\text { Score }\end{array}$ & $\begin{array}{c}\text { FORMED } \\
\text { SUB-STRICT } 2\end{array}$ & $\begin{array}{l}\text { Nominated } \\
\text { RW }\end{array}$ & $\begin{array}{l}\text { Total } \\
\text { Score }\end{array}$ & $\begin{array}{c}\text { PARENT } \\
\text { SUB-DISTRICT }\end{array}$ & $\begin{array}{l}\text { Nominated } \\
\text { RW }\end{array}$ & $\begin{array}{l}\text { Total } \\
\text { Score }\end{array}$ \\
\hline 1 & & RW 07 & 902 & & RW 12 & 1009 & & RW 01 & 902 \\
\hline 2 & & RW 08 & 987 & & RW 13 & 917 & & RW 02 & 1129 \\
\hline 3 & & RW 09 & 1088 & & RW 14 & 1159 & & RW 03 & 902 \\
\hline 4 & & RW 10 & 1018 & & RW 15 & 1210 & & RW 04 & 1106 \\
\hline 5 & & RW 11 & 1011 & & RW 16 & 1015 & & RW 05 & 902 \\
\hline \multirow[t]{3}{*}{6} & & & & & & & & RW 06 & 917 \\
\hline & \multicolumn{2}{|l|}{ TOTAL } & 5006 & & & 5310 & & & 5858 \\
\hline & \multicolumn{2}{|l|}{ AVERAGE } & 1001 & & & 1062 & & & 976 \\
\hline \multicolumn{3}{|c|}{ TOTAL MINIMUM SCORE } & 902 & & & 917 & & & 902 \\
\hline \multicolumn{3}{|c|}{ TOTAL MAXIMUM SCORE } & 1088 & & & 1210 & & & 1129 \\
\hline
\end{tabular}

Source: Data Processing, 2017. 
with nominated RWs: RW 01, RW 02, RW 03, RW 04, RW 05 and RW 06.

\section{2) Formation of Tanjungpura Sub-district Alternative 2}

As shown in Table 19, Mapping of RWs in Tanjungpura Sub-district in alternative 2 is formed sub-district 1 with nominated RWs: RW 07, RW 08, RW 09, RW 10 and RW 11. Formed sub-district 2 with nominated RWs: RW 12, RW 13, RW 14, RW 15, and RW 16. Parent sub-district with nominated RWs: RW 01, RW 02, RW 03, RW 04, RW 05 and RW 06.

Based on comparison of potential as shown in Table 20, it can be explained that in alternative 1, comparison between proposed parent sub-district and proposed formed sub-district is by -55 , which means that proposed parent sub-district has lower potential than proposed formed sub-district. In alternative 2, comparison between proposed parent sub-district and proposed formed sub-district 1 and 2 are by -25 and -86 respectively, which means that proposed parent sub-district has lower potential than both proposed formed sub-districts. Therefore, it is clear that alternative 1 is decided to be choice 1 . This is based on consideration that formation according to division of governmental operational area is relatively more balanced in terms of potential than formation by alternative 1 regarding the 19 variables. Difference between proposed parent sub-district and proposed formed sub-district in alternative 1 is only -55 .

\section{Conclusions}

Balance in real and potential capacity of sub-districts, either proposed formed sub-district and proposed parent sub-district, after the formation should be relatively maintained. Therefore, the choice of action is based on the alternative with the smallest difference of total score. Formation should also ensure the improvement of public services, democratization, and social welfare, of both proposed formed sub-district and proposed parent sub-district after the formation. Priority choice for formation of sub-district should be determined according to criteria on the lowest difference between results of proposed sub-districts, of both proposed created sub-district and proposed formed sub-district/proposed parent sub-district after formation, by considering public aspiration. This criterion is chosen with consideration:

1) Formation of sub-district should not make proposed parent sub-district become weak or incapable to administer its autonomy;

Table 20. Mapping of RWs in Tanjungpura Sub-district.

\begin{tabular}{ccccc}
\hline & \multicolumn{3}{c}{ Score Average } \\
\cline { 2 - 4 } Mapping & $\begin{array}{c}\text { Parent } \\
\text { Sub-district }\end{array}$ & $\begin{array}{c}\text { Formed } \\
\text { Sub-district 1 }\end{array}$ & $\begin{array}{c}\text { Formed } \\
\text { Sub-district 2 }\end{array}$ & Difference \\
\hline Scenario 1 & 976 & 1032 & 1062 & -55 \\
Scenario 2 & 976 & 1001 & -25 \\
\end{tabular}

Source: Data Processing, 2017. 
2) Difference of capability between proposed formed sub-district and proposed parent sub-district after the formation should not have significant discrepancy;

3) Balance in real and potential capacity of sub-districts, either proposed formed sub-district and proposed parent sub-district, after the formation should be relatively maintained;

4) Formation should ensure the improvement of public services, democratization, and social welfare, of both proposed formed sub-district and proposed parent sub-district after the formation.

\section{Conflicts of Interest}

The authors declare no conflicts of interest regarding the publication of this paper.

\section{References}

[1] Sadu, W. (2001) Essence of Law Number 22 Year 1999 Regarding Regional Government (Bunga Rampai). Alqaprint, Jatinangor Indonesia.

[2] Surparni, P. (1985) Implementation of Decentralization and Regional Autonomy Principles in Administration System of the Unitary State of the Republic of Indonesia. Departement of Home Affairs, Jakarta Indonesia.

[3] Fernandes, S. (2014) Organizational Transformation of Village Status Changes into Urban Area (Kelurahan). Alfabeta, Bandung Indonesia.

[4] Ministry of Home Affairs Law No. 23 of 2014 on Local Government and 23 Indonesia, 2014 Regulation.

[5] Sadu, W. (2004) Capita Selecta Implementation of Local Government. 4th Edition, Fokusmedia, Bandung Indonesia.

[6] Ministry of Home Affairs Law No. 32 of 2004 on Local Government 32 Indonesia, 2004 Regulation.

[7] Government Regulation No. 73 of 2005 on Sub-District (Kelurahan). Indonesia, 2005. Regulation.

[8] Fernandes, S. (2016) Research Methodology on Administration. Alfabeta, Bandung Indonesia. 